\title{
Wioletta Kamińska
}

Uniwersytet Jana Kochanowskiego w Kielcach, Instytut Geografii

\section{Kapitał ludzki a spójność ekonomiczna obszarów wiejskich w Polsce}

\begin{abstract}
Zarys treści: Celem pracy jest próba określenia relacji między kapitałem ludzkim rozumianym jako zasób wiedzy społeczeństwa a stopniem spójności ekonomicznej obszarów wiejskich w Polsce. Dla określenia spójności ekonomicznej skonstruowano syntetyczny miernik w oparciu o 9 mierników cząstkowych obrazujących sytuację finansową, gospodarczą i infrastrukturalną obszarów wiejskich. Jako miernik kapitału ludzkiego przyjęto odsetek ludności z wykształceniem co najmniej średnim. Analizę przeprowadzono na poziomie powiatów. Wykazała ona, że istnieje co najwyżej umiarkowana zależność między badanymi cechami. Współczynnik korelacji liczony dla całej zbiorowości jednostek przestrzennych wyniósł zaledwie 0,173 , a determinacji 0,03. Natomiast współczynnik korelacji liczony dla zbiorowości jednostek przestrzennych pomniejszonej o powiaty drastycznie odbiegające od zauważonych tendencji wynosił 0,404, a determinacji 0,163. Oznacza to, że o poziomie spójności ekonomicznej w głównym stopniu decydowały inne czynniki.
\end{abstract}

Słowa kluczowe: spójność ekonomiczna, wykształcenie, obszary wiejskie

\section{Wstęp}

Członkostwo Polski w Unii Europejskiej wywołało wiele konsekwencji natury gospodarczej, społecznej i politycznej. Jedną z nich była konieczność prowadzenia polityki spójności, która polega na wyrównaniu dysproporcji regionalnych. Polityka ta realizowana jest poprzez działania na rzecz wzrostu gospodarczego, zwiększenia konkurencyjności regionów oraz zatrudnienia i opiera się na trzech filarach: spójności ekonomicznej, społecznej i terytorialnej (Kamińska, Mularczyk 2014). Zmniejszanie dysparytetów regionalnych było możliwe głównie dzięki funduszom strukturalnym, które Polska otrzymywała od 2004 r. Właśnie zakończyła się perspektywa finansowania na lata 2007-2013, toteż w literaturze pojawiły się próby ewaluacji wydatkowanych środków unijnych (Wpływ wspólnej polityki... 2011, Zaleski i in. 2010, Kamińska, Mularczyk 2014, Kołodziejczyk 2014). Wyniki tych badań sugerują, że w zakresie spójności terytorialnej i społecznej widoczna jest tendencja do konwergencji, natomiast w przypadku spójności ekonomicznej mamy do czynienia ze wzrostem różnic regionalnych. 
W wielu badaniach podkreśla się także, że stopień spójności ekonomicznej może być uzależniony od kapitału ludzkiego (Klimczak 2002, Jabłoński 2005, Roszkowska 2006, Kamińska, Mularczyk 2014, Kołodziejczyk 2014). Toteż miasta, gdzie kapitał ludzki jest wysokiej jakości, rozwijają się szybciej aniżeli obszary wiejskie, gdzie poziom kapitału ludzkiego jest niższy.

W świetle powyższych uwag w niniejszym artykule podjęto próbę określenia relacji między kapitałem ludzkim a stopniem spójności ekonomicznej obszarów wiejskich w Polsce. Przeprowadzono tteż typologię tych obszarów ze względu na powyższe relacje. W pracy kapitał ludzki rozumiany jest jako zasób wiedzy społeczeństwa (The Well-being... 2001), natomiast spójność ekonomiczną analizowano $\mathrm{w}$ powiązaniu $\mathrm{z}$ poziomem rozwoju społeczno-gospodarczego danego obszaru wynikającym ze stanu i struktury gospodarki, poziomu rozwoju infrastruktury oraz sytuacji finansowej podmiotów gospodarczych. Zmniejszanie różnic w układzie wewnątrzregionalnym w ramach tych aspektów rozwoju społeczno-gospodarczego interpretowano jako wzrost spójności ekonomicznej (por. Churski 2009). W postępowaniu badawczym zmierzano do odpowiedzi na następujące pytania:

1. Czy istnieje statystyczna zależność między odsetkiem ludności z wykształceniem co najmniej średnim a syntetycznym wskaźnikiem spójności ekonomicznej?

2. W jakim stopniu zmienność odsetka ludności z wykształceniem co najmniej średnim wpływa na zmienność wskaźnika spójności ekonomicznej?

3. Jakie są typy obszarów wiejskich ze względu na zależność między badanymi zmiennymi?

4. Jakie są prawidłowości w rozmieszczeniu poszczególnych typów obszarów wiejskich (powiatów)?

Zakres czasowy pracy obejmuje lata 2004-2011. Przyjęcie takiego horyzontu czasowego było związane ze wstąpieniem Polski do UE w roku 2004. Uznano, że było to jednocześnie początkiem nowego etapu kształtowania się polityki regionalnej, w tym wprowadzania instrumentów polityki spójności. Należy podkreślić, że w okresie tym Polska była beneficjentem środków europejskich w ramach Regionalnego Programu Operacyjnego, Programu Operacyjnego Kapitał Ludzki, Programu Operacyjnego Rozwój Polski Wschodniej, Programu Rozwoju Obszarów Wiejskich (Rudnicki 2010). Napływające fundusze zostały zainwestowane i wykorzystane $\mathrm{w}$ analizowanym czasie. W związku z tym przyjęto, że ośmioletni okres jest wystarczający do ustalenia tendencji zmian w rozwoju ekonomicznym wsi (Kamińska, Mularczyk 2014). Badaniem objęto obszary wiejskie według powiatów.

\section{Metody badań}

W pracy przyjęto, że poziom kapitału ludzkiego można mierzyć odsetkiem ludności z wykształceniem co najmniej średnim w ogólnej liczbie ludności dorosłej. Udział osób o najwyższym poziomie wykształcenia jest powszechnie przyjmowa- 
ny jako podstawowy miernik kapitału ludzkiego (Chojnicki, Czyż 2003, López-Rodriguez i in. 2007, Lopez-Bazo, Moreno 2008, Kamińska 2010a, 2013). Poziom wykształcenia wynika z samej definicji kapitału ludzkiego i jest jego najbardziej precyzyjną z dostępnych miar, mimo że pomija aspekty jakościowe edukacji.

Spójność ekonomiczną obszarów wiejskich natomiast oceniono na podstawie syntetycznego wskaźnika zmian, który był sumą trzech cząstkowych obrazujących sytuację finansową, gospodarczą i infrastrukturalną powiatów (por. Swianiewicz 2007, Churski 2009).

Jako miernik sytuacji finansowej przyjęto wzrost dochodów własnych gmin na jednego mieszkańca. Jest to najczęściej stosowana miara rozwoju zamożności jednostek administracyjnych (Hryniewicz 2000, Sobala-Gwosdz 2003, Kamińska 2013), a jej wady zostały opisane w literaturze. Swianiewicz (2007) stwierdził, że dochody własne gmin stosunkowo słabo mierzą poziom zamożności obszarów wiejskich ze względu na to, że rolnicy nie płacą podatku PIT. Dodatkowo wskaźnik ten tylko do pewnego stopnia odnosi się do bazy podatkowej. Rzeczywiste dochody zależą od indywidualnej polityki prowadzonej przez gminy, np. w zakresie ulg i zwolnień z podatku.

Jako mierniki sytuacji gospodarczej wykorzystano: wzrost/spadek liczby podmiotów zarejestrowanych w systemie REGON, wzrost dochodów z podatku od osób prawnych (CIT) na 1 mieszkańca oraz spadek stopy bezrobocia (liczony jako udział bezrobotnych w liczbie ludności w wieku produkcyjnym). Mając na uwadze powszechność stosowania wymienionych mierników (Chojnicki, Czyż 2003, Ślusarz 2005, Kacprzak 2010, Kamińska 2013), należy zwrócić uwagę na ich słabe strony. Liczba podmiotów gospodarczych w systemie REGON może być zawyżona z powodu braku obowiązku wyrejestrowywania podmiotów, których działalność została zawieszona lub które zostały zlikwidowane. Nadto liczba podmiotów może być zniekształcona ze względu na zjawisko samozatrudnienia, które nierzadko jest wymuszane poprzez potencjalnych pracodawców/kooperantów (Kamińska 1999, 2006). Dlatego w niniejszym badaniu uwzględniono również dochody z podatku od osób prawnych (CIT) na 1 mieszkańca. Wskaźnik ten pokazuje rzeczywistą (nie tylko zarejestrowaną) aktywność gospodarczą na terenach wiejskich. Z kolei stopa bezrobocia może być zaniżona z uwagi na występowanie bezrobocia ukrytego (które związane jest z rozdrobnieniem gospodarstw rolnych) oraz zatrudniania w szarej strefie.

Dla opisania sytuacji infrastrukturalnej obszarów wiejskich wykorzystano: wzrost/spadek odsetka ludności korzystającej z kanalizacji oraz sieci gazowej, wzrost powierzchni użytkowej mieszkań, wzrost długości dróg gminnych o nawierzchni twardej oraz zmiany liczby mieszkańców korzystających z oczyszczalni ścieków. Wskaźniki rozwoju sieci kanalizacji sanitarnej i związanej z ochroną środowiska należą do powszechnie wykorzystywanych miar sytuacji infrastrukturalnej (Sobala-Gwosdz 2003, Baran, Grzebyk 2011, Kamińska 2013). Świadczą one nie tylko o możliwościach finansowych samorządów lokalnych, ale także o inwencji i potrzebach mieszkańców. Inwestycje w urządzenia sanitarne podnoszą atrakcyjność lokalizacyjną i osiedleńczą jednostek osadniczych. Jednak zainwestowanie $\mathrm{w}$ ten rodzaj infrastruktury w dużej mierze uzależnione jest od 
stopnia rozproszenia sieci osadniczej i ukształtowania powierzchni (Kamińska 2010b), a przyjęte miary nie uwzględniają tych warunków. Zmiany powierzchni użytkowej mieszkań wzięto pod uwagę, aby podkreślić znaczenie inwestycji prowadzonych nie tylko przez samorządy ale także przez osoby prywatne. Długość dróg gminnych o nawierzchni twardej wskazuje na działalność inwestycyjną samorządów lokalnych, na wysokość absorbcji środków unijnych oraz na stopień atrakcyjności inwestycyjnej jednostek osadniczych.

Wszystkie przyjęte cechy mają charakter dynamiczny, a zatem analizowano wzrost/spadek danej cechy w badanym okresie. Uwzględniono stan na rok 2004 i 2011. W pierwszym etapie konstrukcji wskaźnika syntetycznego wszystkie cechy poddano procedurze standaryzacji według wzoru:

$$
X=\frac{X_{2011}-X_{2004}}{\bar{X}_{2004}}
$$

gdzie:

$X^{\prime}$ - cecha standaryzowana,

$X_{2011}$ - wartość cechy w 2011 r.,

$X_{2004}$ - wartość cechy w 2004 r.,

$\bar{X}_{2004}$ - średnia wartość cechy w $2004 \mathrm{r}$.

Podobną procedurę zastosował Swianiewicz (2007), analizując stan spójności ekonomicznej i społecznej Polski wschodniej. Jak wskazał cytowany autor metoda ta pozwala na uniknięcie sytuacji, w której na końcowy wynik wpływa niewielki nawet postęp przy bardzo niskim stanie wyjściowym. W kolejnym etapie wyliczono cząstkowe wskaźniki sytuacji finansowej, gospodarczej i infrastrukturalnej obszarów wiejskich. Stanowią one sumę przekształconych cech przyjętych do analizy.

Do zbadania zależności między kapitałem ludzkim a spójnością ekonomiczną obszarów wiejskich wykorzystano współczynnik korelacji Pearsona. Natomiast dla określenia, w jakim stopniu zmienność kapitału ludzkiego wpływa na zmienność spójności ekonomicznej, wyliczono współczynnik determinacji. Obydwa współczynniki (korelacji i determinacji) wyliczono dla wszystkich jednostek przestrzennych (314 powiatów) oraz dla zbiorowości pomniejszonej o jednostki drastycznie odbiegające od istniejącej tendencji $(\sigma>3)$. Przyjęto bowiem, że takie powiaty mogą oddziaływać deformująco na otrzymane wyniki. Należy jednak pamiętać, że istnieją one w rzeczywistości i wpływają na relacje między badanymi zmiennymi. Toteż całkowite ich pomijanie $\mathrm{w}$ analizie także zniekształca ostateczne wyniki. Warto przy tym podkreślić, że to właśnie powiaty o najwyższych wskaźnikach spójności ekonomicznej osiągnęły realny sukces gospodarczy i mogą (powinny) być wzorcem do naśladowania.

W pracy wykorzystano ponadto współczynnik zmienności oraz iloraz lokalizacji. 


\section{Spójność ekonomiczna a kapitał ludzki - stan badań w Polsce}

Pojęcie spójności ekonomicznej wykorzystywane jest zazwyczaj w dwóch kontekstach: tradycyjnym i nowoczesnym. W pierwszym z nich spójność utożsamiana jest z procesem bezwarunkowej konwergencji, a więc zmniejszaniem różnic w poziomie rozwoju gospodarczego regionów. Kontekst nowoczesny zaś wiąże spójność z funkcjonalnym i harmonijnym rozwojem regionów w oparciu o endogeniczny potencjał (Gąska i in. 2009).

W polskiej literaturze przedmiotu rzadko podejmowana była problematyka zależności między spójnością ekonomiczną a kapitałem ludzkim. Zazwyczaj były to dwie oddzielne grupy prac; w pierwszej eksponowano różnice regionalne w rozwoju gospodarczym - ich wzrost lub spadek, w drugiej analizowano zależności między kapitałem ludzkim a wybranymi aspektami życia społeczno-gospodarczego.

Autorzy podejmujący problematykę kohezji zwykle koncentrowali się na ewaluacji polityki spójności prowadzonej albo w kraju, albo w poszczególnych jego regionach (Gorzelak 2007, Swianiewicz 2007, Zaleski i in. 2010, Kołodziejczyk 2014), a ich wyniki często zależały od przyjętych mierników i od skali badań (lokalna, regionalna, krajowa).

Wielu autorów podkreślało pozytywny wpływ działań kohezyjnych na zmniejszanie dysparytetów regionalnych. Zwracano przy tym uwagę na wzmocnienie potencjału endogenicznego (Wpływ wspólnej polityki... 2011), rozwój infrastruktury technicznej i społecznej (Kamińska, Mularczyk 2014, Kołodziejczyk 2014), poprawę warunków życia ludności (Zaleski i in. 2010) oraz wzrost innowacyjności, zwłaszcza w ośrodkach miejskich (Celińska-Janowicz i in. 2010).

W literaturze są również przykłady prac, w których autorzy wskazywali na wzrost dysproporcji rozwojowych pomiędzy poszczególnymi regionami kraju. Na przykład Gorzelak (2007) stwierdził, że różnica między poziomem rozwoju Polski wschodniej a resztą kraju mierzona wartością PKB na jednego mieszkańca na początku XXI w. powiększyła się. Swianiewicz (2007) z kolei zauważył, że większość wskaźników opisujących spójność ekonomiczną Polski wschodniej na poziomie powiatów i gmin kształtowała się poniżej średniej dla kraju.

Kołodziejczyk (2014) dostrzegła wyraźne różnice pod względem poziomu spójności gospodarczej w trzech typach gmin: miejskich, miejsko-wiejskich i wiejskich, przy czym dwa pierwsze typy jednostek administracyjnych wykazały wyższy poziom aniżeli ostatni. Cytowana autorka stwierdziła, że w latach 20052012 nastąpił wzrost zróżnicowania między typami gmin, a także między rodzajami gmin wewnątrz województw. Powiększanie się zróżnicowania oznaczało zmniejszenie się stopnia lokalnej spójności.

Natomiast badania Kamińskiej i Mularczyka (2014) wykazały, że mimo prowadzonej w Polsce polityki spójności w latach 2004-2011 nie doszło do znaczącego zniwelowania różnic rozwojowych między obszarami wiejskimi Polski wschodniej i zachodniej. Przyczyniło się do tego przede wszystkim tempo zmian kondycji finansowej i zmian w poziomie przedsiębiorczości. Dynamika wzrostu 
dochodów własnych oraz budżetowych gmin w przeliczeniu na jednego mieszkańca była wyższa na obszarach wiejskich województw zachodnich niż wschodnich. W regionach zachodnich kraju występował dużo większy, w stosunku do województw wschodnich, odsetek gmin charakteryzujących się ponadprzeciętnym wzrostem przedsiębiorczości i spadkiem stopy bezrobocia. Jedynie dynamika zmian infrastrukturalnych wpływała na niwelowanie różnic. Wysokie tempo zmian infrastrukturalnych na obszarach wiejskich województw wschodnich było skutkiem dobrego wykorzystania funduszy pomocowych UE.

Z kolei badania nad kapitałem ludzkim w Polsce były prowadzone od końca ubiegłego stulecia. Poszczególne prace dotyczyły przede wszystkim aspektów empirycznych i były skoncentrowane głównie na pomiarze jego poziomu (zasobów) (Swianiewicz i in. 2008, Janc 2009, Kamińska 2010a, 2011, Zioło 2010). Rzadko autorzy studiów podejmowali dyskusję na temat wpływu kapitału ludzkiego na rozwój społeczno-gospodarczy (Czapiński 2008), przyjmując raczej taką zależność za oczywistą.

Spośród nielicznych prac należy wymienić te, w których wykazano pozytywną korelację między wykształceniem a: efektami produkcyjnymi gospodarstw rolnych (Gałczyńska, Kulikowski 1986, Kulikowski 2001, Wawrzyniak 2001), poziomem rozwoju obszarów wiejskich (Janc, Czapiewski 2005, Kamińska 2013), sytuacją ekonomiczną gospodarstw rolnych (Golębiewska, Klepacki 2004), poziomem i jakością życia ludności (Stawicka, Wołoszyn 2007), możliwościami absorbcji innowacji w gospodarstwach rolnych (Gałczyńska 1998) oraz pozyskiwaniem funduszy z UE (Bański, Stola 2002, Ciok, Rabczyk 2006).

\section{Kapitał ludzki na obszarach wiejskich w Polsce - przestrzenne zróżnicowanie}

W 2011 r. na obszarach wiejskich Polski osoby z wykształceniem co najmniej średnim stanowiły ponad $1 / 3(37 \%)$ dorosłej ludności. W stosunku do $2002 \mathrm{r}$. odsetek ten powiększył się o 11,1 pp. Był to wzrost spektakularny zważywszy na to, że w analizowanym okresie liczba ludności utrzymywała się prawie na niezmienionym poziomie (spadek o 0,8\%). Nadal jednak mieliśmy do czynienia $\mathrm{z}$ niedoborem osób $\mathrm{z}$ tym poziomem wykształcenia w stosunku do liczby mieszkańców. Iloraz lokalizacji ${ }^{1}$ wyniósł 0,71 .

W poszczególnych powiatach odsetek mieszkańców legitymujących się posiadaniem co najmniej średniego wykształcenia wahał się od $24,3 \%$ do $65,6 \%$ (tab. 1, ryc. 1). Najbardziej niekorzystną strukturę wykształcenia zanotowano w 45 powiatach, skupiających blisko 1/10 mieszkańców polskiej wsi. Prawie wszystkie

Iloraz lokalizacji liczony był jako stosunek odsetka ludności wsi z wykształceniem co najmniej średnim do odsetka mieszkańców wsi. Wartość powyżej 1 świadczy o nadreprezentacji osób z danym poziomem wykształcenia w stosunku do potencjału demograficznego; wartość mniejsza od 1 oznacza niedobór tej grupy osób, natomiast jeśli iloraz równa się 1, mamy do czynienia z równowagą obydwu cech. 


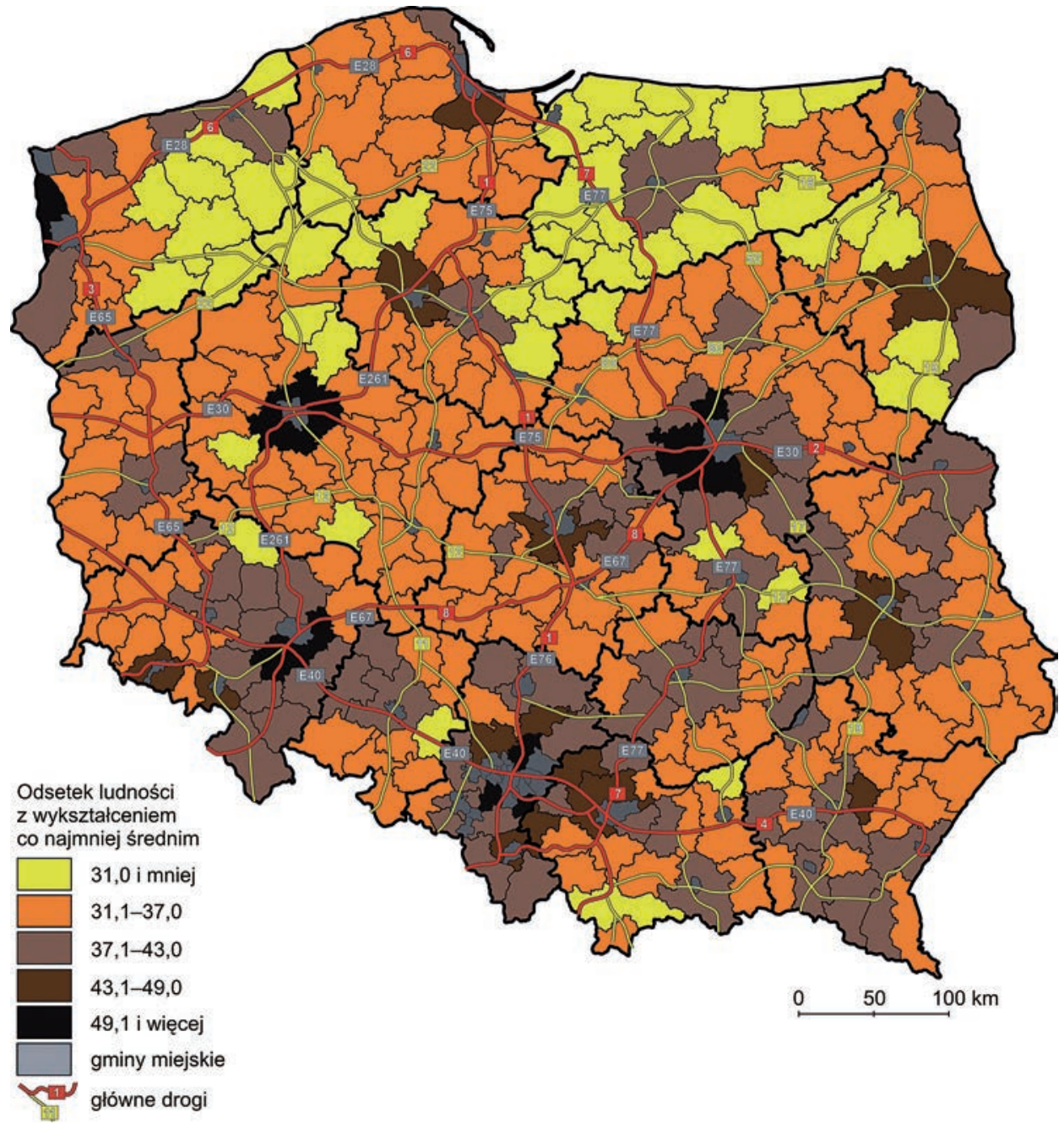

Ryc. 1. Odsetek osób z wykształceniem co najmniej średnim w ogólnej liczbie ludności dorosłej na obszarach wiejskich Polski w 2011 r.

Źródło: opracowanie własne na podstawie danych z BDL, GUS.

były skoncentrowane w czterech województwach: warmińsko-mazurskim, podlaskim, zachodniopomorskim i kujawsko-pomorskim, a więc na obszarach rolniczych, o dużym udziale (do 1989 r.) wielkoobszarowego rolnictwa uspołecznionego. Stosunkowo niski udział osób najlepiej wyedukowanych $(31,1-37 \%)$ wystąpił także w kolejnych 167 powiatach $(53,2 \%)$, na których terenie mieszkała ponad połowa ludności wiejskiej. Obszary te znajdowały się w całym kraju, najczęściej z dala od największych miast poszczególnych regionów. Łącznie wymienione jednostki przestrzenne stanowiły $2 / 3$ ich ogólnej liczby. Na ich terenie udział ludności o najwyższych formalnych kwalifikacjach kształtował się poniżej średniej. 
Tabela 1. Zróżnicowanie odsetka osób z wykształceniem co najmniej średnim na obszarach wiejskich w Polsce w 2011 r.

\begin{tabular}{|c|c|c|c|c|c|c|c|}
\hline \multirow[b]{2}{*}{$\begin{array}{l}\text { Odsetek osób } \\
\text { z wykształce- } \\
\text { niem co naj- } \\
\text { mniej średnim }\end{array}$} & \multicolumn{3}{|c|}{ Liczba } & \multicolumn{3}{|c|}{ Odsetek } & \multirow[b]{2}{*}{$\begin{array}{c}\text { Iloraz } \\
\text { lokali- } \\
\text { zacji }\end{array}$} \\
\hline & powiatów & $\begin{array}{l}\text { ludności } \\
\text { [tys.] }\end{array}$ & $\begin{array}{l}\text { osób z wykształ- } \\
\text { ceniem co naj- } \\
\text { mniej średnim } \\
\text { [tys.] }\end{array}$ & powiatów & ludności & $\begin{array}{c}\text { osób z wy- } \\
\text { kształce- } \\
\text { niem co } \\
\text { najmniej } \\
\text { średnim }\end{array}$ & \\
\hline 31,0 i mniej & 45 & 1407,2 & 324,9 & 14,3 & 9,3 & 7,0 & 0,75 \\
\hline $31,1-37,0$ & 167 & 7622,4 & 2124,1 & 53,2 & 50,5 & 45,5 & 0,90 \\
\hline $37,1-43,0$ & 75 & 4227,6 & 1369,2 & 23,9 & 28,0 & 29,3 & 1,05 \\
\hline $43,1-49,0$ & 16 & 1144,6 & 426,7 & 5,1 & 7,6 & 9,1 & 1,21 \\
\hline 49,1 i więcej & 11 & 704,2 & 426,7 & 3,5 & 4,7 & 9,1 & 1,96 \\
\hline razem & 314 & 15105,9 & 4671,6 & 100,0 & 100,0 & 100,0 & 1,00 \\
\hline
\end{tabular}

Źródło: obliczenia własne na podstawie BDL.

W stosunku do potencjału demograficznego mieliśmy do czynienie z niedoborem tej grupy osób - iloraz lokalizacji poniżej 1.

$\mathrm{Na}$ pozostałych obszarach wiejskich analizowany wskaźnik przyjmował wartości ponadprzeciętne. Takich powiatów było 102, na ich terenie mieszkało $40 \%$ ludności wiejskiej oraz blisko połowa wszystkich mieszkańców wsi, którzy ukończyli co najmniej szkołę średnią. Najkorzystniejszą strukturę wykształcenia miały obszary położone w sąsiedztwie aglomeracji, wzdłuż głównych szlaków komunikacyjnych oraz o dobrze rozwiniętym przemyśle (tereny wchodzące $\mathrm{w}$ skład największych okręgów przemysłowych PRL).

Rozkład przestrzenny analizowanego wskaźnika można objaśniać w świetle koncepcji rdzeń-peryferia. Wysokie wartości przyjmuje on w powiatach położonych w sąsiedztwie wielkich miast, przy czym maksimum osiąga wokół dużych ośrodków miejskich centralnej i zachodniej Polski (Warszawa, Poznań, Wrocław, Szczecin). W miarę oddalania się od aglomeracji analizowany wskaźnik obniża się, osiągając wartości minimalne na peryferiach poszczególnych województw².

\section{Spójność ekonomiczna wiejskich obszarów w Polsce - wskaźnik syntetyczny}

Syntetyczny wskaźnik spójności ekonomicznej na obszarach wiejskich Polski wahał się od 0,399 do 58,525, przy średniej 3,933. Wskaźnik zmienności (V) wyniósł 101,5\% (tab. 2), co oznacza wysoką dyspersję. W strukturze tego wskaźnika największe znaczenie miały mierniki obrazujące spójność infrastrukturalną, a najmniejsze opisujące sytuację finansową obszarów wiejskich. Stanowiły one kolejno 47,3\% i 21,2\% ogólnej wartości syntetycznego wskaźnika spójności ekonomicznej. Największą zmiennością przestrzenną odznaczał się wskaźnik

\footnotetext{
2 Szerzej na ten temat: Kamińska 2014a, b.
} 
Tabela 2. Wartości i podstawowe charakterystyki statystyczne wskaźników spójności: finansowej, gospodarczej i infrastrukturalnej na obszarach wiejskich Polski

\begin{tabular}{lccccc}
\hline \multirow{2}{*}{ Wskaźnik spójności } & \multicolumn{3}{c}{ Wartość } & Mediana & $\begin{array}{c}\text { Współczynnik } \\
\text { zmienności V [\%] }\end{array}$ \\
\cline { 2 - 4 } & średnia & minimalna & maksymalna & & 47,7 \\
\hline Finansowej & 0,831 & $-0,509$ & 3,494 & 0,759 & 291,3 \\
Gospodarczej & 1,239 & $-1,954$ & 53,020 & 0,675 & 51,2 \\
Infrastrukturalnej & 1,860 & $-0,294$ & 5,320 & 1,670 & 101,5 \\
Syntetyczny wskaźnik ogółem & 3,933 & 0,399 & 58,525 & 3,305 & \\
\hline
\end{tabular}

Źródło: obliczenia własne

spójności gospodarczej odzwierciedlający poziom przedsiębiorczości, wpływy z podatku dochodowego od osób prawnych oraz stopę bezrobocia. Wskaźnik zmienności wyniósł ponad 290\%. Mierniki spójności finansowej i infrastrukturalnej nie wykazywały tak silnego zróżnicowania w przestrzeni - ich zmienność wynosiła $47-51 \%$. W przypadku infrastruktury było to związane z wykorzystaniem środków unijnych, zwłaszcza z programu Polska Wschodnia, dzięki którym różnice regionalne uległy zmniejszeniu. Natomiast w przypadku finansów oznaczało to, że władze lokalne prowadziły mało zróżnicowaną politykę dotyczącą wpływów budżetowych.

Przyjmując jako kryterium wartość syntetycznego wskaźnika spójności ekonomicznej, wyróżniono cztery klasy powiatów (obszarów wiejskich) (tab. 3, ryc. 2).

Pierwsza klasa o niskiej spójności (wskaźnik poniżej średniej dla obszarów wiejskich) obejmowała aż 203 powiaty (ok. 65\%), skupiające prawie 60\% ludności wiejskiej kraju (tab. 3). Zlokalizowane one były głównie we wschodnich regionach kraju (tab. 4, ryc. 2). W pięciu województwach tworzących w nomenklaturze unijnej Polskę wschodnią (warmińsko-mazurskie, podlaskie, lubelskie, podkarpackie i świętokrzyskie) takich powiatów było 62, co stanowiło ponad $30 \%$ ogólnej liczby jednostek przestrzennych z klasy pierwszej. W województwie podlaskim wszystkie powiaty zaliczono do tej grupy, w lubelskim $85 \%$ jednostek przestrzennych, a w warmińsko-mazurskim $84 \%$ (tab. 4).

Z pozostałych regionów kraju dużą koncentracją powiatów o niskiej spójności ekonomicznej (powyżej 70\%) odznaczały się województwa łódzkie, kujawsko-pomorskie oraz śląskie. Natomiast najmniej jednostek przestrzennych zaliczonych do klasy pierwszej zlokalizowanych było w województwie opolskim, w którym średnio co czwarty powiat znajdował się w tej grupie.

Generalizując, można stwierdzić, że w grupie tej znalazły się: po pierwsze powiaty o przewadze funkcji rolniczych (Bański, Stola 2002), dominacji (do 1989 r.) wielkoobszarowych uspołecznionych gospodarstw rolnych (Zgliński 2000) oraz rozproszonej wiejskiej sieci osadniczej (Brol 1996, Kamińska 2010b), po drugie jednostki przestrzenne położone peryferyjnie w obrębie województw.

$\mathrm{Na}$ obszarach tych najlepiej przedstawiała się sytuacja infrastrukturalna, a najgorzej gospodarcza. Przeciętne wskaźniki spójności kształtowały się: 1,462 (infrastruktura) i 0,495 (gospodarka). Potwierdziło to duże znaczenie unijnych środków na budowę dróg, sieci kanalizacyjnej, gazowej oraz oczyszczalni ścieków 
Tabela 3. Przestrzenne zróżnicowanie syntetycznego wskaźnika spójności ekonomicznej na obszarach wiejskich Polski

\begin{tabular}{|c|c|c|c|c|c|c|c|c|}
\hline \multirow{2}{*}{$\begin{array}{l}\text { Syntetyczny } \\
\text { wskaźnik spój- } \\
\text { ności ekono- } \\
\text { micznej (klasa } \\
\text { spójności) }\end{array}$} & \multicolumn{2}{|c|}{ Liczba } & \multicolumn{2}{|c|}{ Odsetek } & \multicolumn{3}{|c|}{$\begin{array}{c}\text { Średni syntetyczny } \\
\text { wskaźnik }\end{array}$} & \multirow{2}{*}{$\begin{array}{l}\text { Przykłady powia- } \\
\text { tów w grupie (3 } \\
\text { o najwyższych i } 3 \\
\text { o najniższych war- } \\
\text { tościach w grupie) }\end{array}$} \\
\hline & $\begin{array}{l}\text { powia- } \\
\text { tów }\end{array}$ & $\begin{array}{l}\text { ludno- } \\
\text { ści }\end{array}$ & $\begin{array}{l}\text { powia- } \\
\text { tów }\end{array}$ & $\begin{array}{l}\text { ludno- } \\
\text { ści }\end{array}$ & $\begin{array}{l}\text { finan- } \\
\text { sowy }\end{array}$ & $\begin{array}{l}\text { gospo- } \\
\text { darczy }\end{array}$ & $\begin{array}{l}\text { infra- } \\
\text { struk- } \\
\text { turalny }\end{array}$ & \\
\hline $\begin{array}{l}\text { 0,000-3,933 } \\
\text { (niska) }\end{array}$ & 203 & 8957,3 & 64,6 & 59,1 & 0,721 & 0,495 & 1,462 & $\begin{array}{l}\text { myszkowski, } \\
\text { nowodworski, } \\
\text { sokólski, kamień- } \\
\text { ski, leszczyński, } \\
\text { mrągowski }\end{array}$ \\
\hline $\begin{array}{l}3,934-7,925 \\
\text { (przeciętna) }\end{array}$ & 99 & 5431,3 & 31,6 & 35,8 & 0,966 & 1,366 & 2,569 & $\begin{array}{l}\text { szczycieński, kut- } \\
\text { nowski, będziński, } \\
\text { oławski, opatow- } \\
\text { ski, krakowski }\end{array}$ \\
\hline $\begin{array}{l}\text { 7,926-11,916 } \\
\text { (wysoka) }\end{array}$ & 6 & 558,9 & 1,9 & 3,7 & 1,289 & 4,360 & 3,455 & $\begin{array}{l}\text { gdański, lubiński, } \\
\text { poznański, wro- } \\
\text { cławski, piaseczyń- } \\
\text { ski, pruszkowski }\end{array}$ \\
\hline $\begin{array}{l}\text { 11,917 i więcej } \\
\text { (bardzo wysoka) }\end{array}$ & 6 & 205,1 & 1,9 & 1,4 & 1,888 & 21,206 & 2,164 & $\begin{array}{l}\text { kozienicki, sta- } \\
\text { szowski, zgorze- } \\
\text { lecki, mikołowski, } \\
\text { bełchatowski, } \\
\text { polkowicki }\end{array}$ \\
\hline razem & 314 & 15152,6 & 100,0 & 100,0 & 0,831 & 1,239 & 1,860 & $x$ \\
\hline
\end{tabular}

Źródło: obliczenia własne.

w rejonach peryferyjnych i typowo rolniczych. Mimo to rozwój przedsiębiorczości i stan rynku pracy na tych terenach był nadal niekorzystny.

Druga klasa obejmująca obszary o przeciętnej spójności ekonomicznej (średnia plus odchylenie standardowe) liczyła 99 powiatów, tj. prawie 1/3 ich ogólnej liczby (tab. 3). Większość zlokalizowana była w Polsce południowej i północno-zachodniej (ryc. 2). Tylko w pięciu województwach: pomorskim, zachodniopomorskim, opolskim, dolnośląskim i wielkopolskim skupionych było ponad $40 \%$ ogółu takich jednostek przestrzennych (tab. 4). Także w województwie podkarpackim, zwłaszcza w jego północnej części, zanotowano dużą koncentrację powiatów odznaczających się przeciętnym poziomem spójności ekonomicznej.

Generalnie w tej grupie znalazły się obszary:

1. Dołączone do Polski po II wojnie światowej, które zawsze odznaczały się ponadprzeciętnym stopniem zainwestowania $\mathrm{w}$ infrastrukturę techniczną (por. Węcławowicz i in. 2006).

2. Położone w sąsiedztwie aglomeracji miejsko-przemysłowych, o dobrze wykształconych funkcjach pozarolniczych (por. Dyba, Stryjakiewicz 2012).

3. Położone $\mathrm{w}$ rejonach wielkoobszarowych gospodarstw rolnych odznaczających się dużą towarowością rolnictwa i/lub rozwiniętymi funkcjami turystycznymi (por. Zgliński 2000, Kulikowski 2013).

4. Położone w rejonach rozdrobnionego rolnictwa, ale odznaczających się gęstą siecią osadniczą (por. Komornicki i in. 2012). 
Tabela 4. Poziom spójności ekonomicznej w powiatach Polski według województw

\begin{tabular}{|c|c|c|c|c|c|}
\hline \multirow[t]{2}{*}{ Województwo } & \multicolumn{4}{|c|}{$\begin{array}{l}\text { Liczba powiatów (odsetek powiatów w ogólnej ich } \\
\text { liczbie w województwie) o poziomie spójności ekono- } \\
\text { micznej: }\end{array}$} & \multirow[t]{2}{*}{ Razem } \\
\hline & niskim & średnim & wysokim & $\begin{array}{c}\text { bardzo } \\
\text { wysokim }\end{array}$ & \\
\hline Łódzkie & $17(81,0)$ & $3(14,3)$ & 0 & $1(4,8)$ & 21 \\
\hline Mazowieckie & $25(67,6)$ & $9(24,3)$ & $2(5,4)$ & $1(2,7)$ & 37 \\
\hline Małopolskie & $13(68,4)$ & $6(31,6)$ & 0 & 0 & 19 \\
\hline Śląskie & $12(70,6)$ & $4(23,5)$ & 0 & $1(5,9)$ & 17 \\
\hline Lubelskie & $17(85,0)$ & $3(15,0)$ & 0 & 0 & 20 \\
\hline Podkarpackie & $8(38,1)$ & $13(61,9)$ & 0 & 0 & 21 \\
\hline Podlaskie & $14(100)$ & $0(0)$ & 0 & 0 & 14 \\
\hline Świętokrzyskie & $7(53,8)$ & $5(38,5)$ & 0 & $1(7,7)$ & 13 \\
\hline Lubuskie & $8(66,7)$ & $4(33,3)$ & 0 & 0 & 12 \\
\hline Wielkopolskie & $16(51,6)$ & $14(45,2)$ & $1(3,2)$ & 0 & 31 \\
\hline Zachodniopomorskie & $9(50,0)$ & $9(50,0)$ & 0 & 0 & 18 \\
\hline Dolnośląskie & $17(65,4)$ & $5(19,2)$ & $2(7,7)$ & $2(7,7)$ & 26 \\
\hline Opolskie & $3(27,3)$ & $8(72,7)$ & 0 & 0 & 11 \\
\hline Kujawsko-pomorskie & $15(78,9)$ & $4(21,1)$ & 0 & 0 & 19 \\
\hline Pomorskie & $6(37,5)$ & $9(56,3)$ & $1(6,3)$ & 0 & 16 \\
\hline Warmińsko-mazurskie & $16(84,2)$ & $3(15,8)$ & 0 & 0 & 19 \\
\hline Razem & $203(64,6)$ & $99(31,5)$ & $6(1,9)$ & $6(1,9)$ & 314 \\
\hline
\end{tabular}

Źródło: obliczenia własne.

Na ogólny wynik syntetycznego wskaźnika spójności ekonomicznej na tych obszarach największy wpływ miał stan infrastruktury i gospodarki. Wskaźnik spójności infrastrukturalnej wyniósł 2,6 i był prawie dwukrotnie wyższy aniżeli w powiatach należących do klasy pierwszej, a wskaźnik spójności gospodarczej równał się 1,5 i był prawie 3-krotnie wyższy aniżeli w klasie poprzedniej.

Do trzeciej klasy zaliczono obszary o wysokim poziomie spójności ekonomicznej. Liczyła ona tylko 6 powiatów, które skupiały prawie $4 \%$ ludności wiejskiej. Należało tu 5 powiatów związanych z wielkimi miastami: gdański, poznański, wrocławski, piaseczyński, pruszkowski) oraz powiat lubiński, z dobrze rozwiniętymi funkcjami przemysłowymi. Na jego terenie zlokalizowana jest m.in. górnicza spółka KGHM Polska Miedź oraz Zakłady Górnicze i Huta Miedzi Cedynia.

We wszystkich wymienionych jednostkach przestrzennych ponadprzeciętnie kształtowały się mierniki opisujące sytuację gospodarczą. Wskaźnik spójności gospodarczej wynosił 4,360 i był 9-krotnie wyższy aniżeli w klasie pierwszej i 3-krotnie wyższy niż w klasie drugiej. Ponadprzeciętnie kształtowały się także mierniki infrastrukturalne. Wskaźnik spójności infrastrukturalnej wynosił 


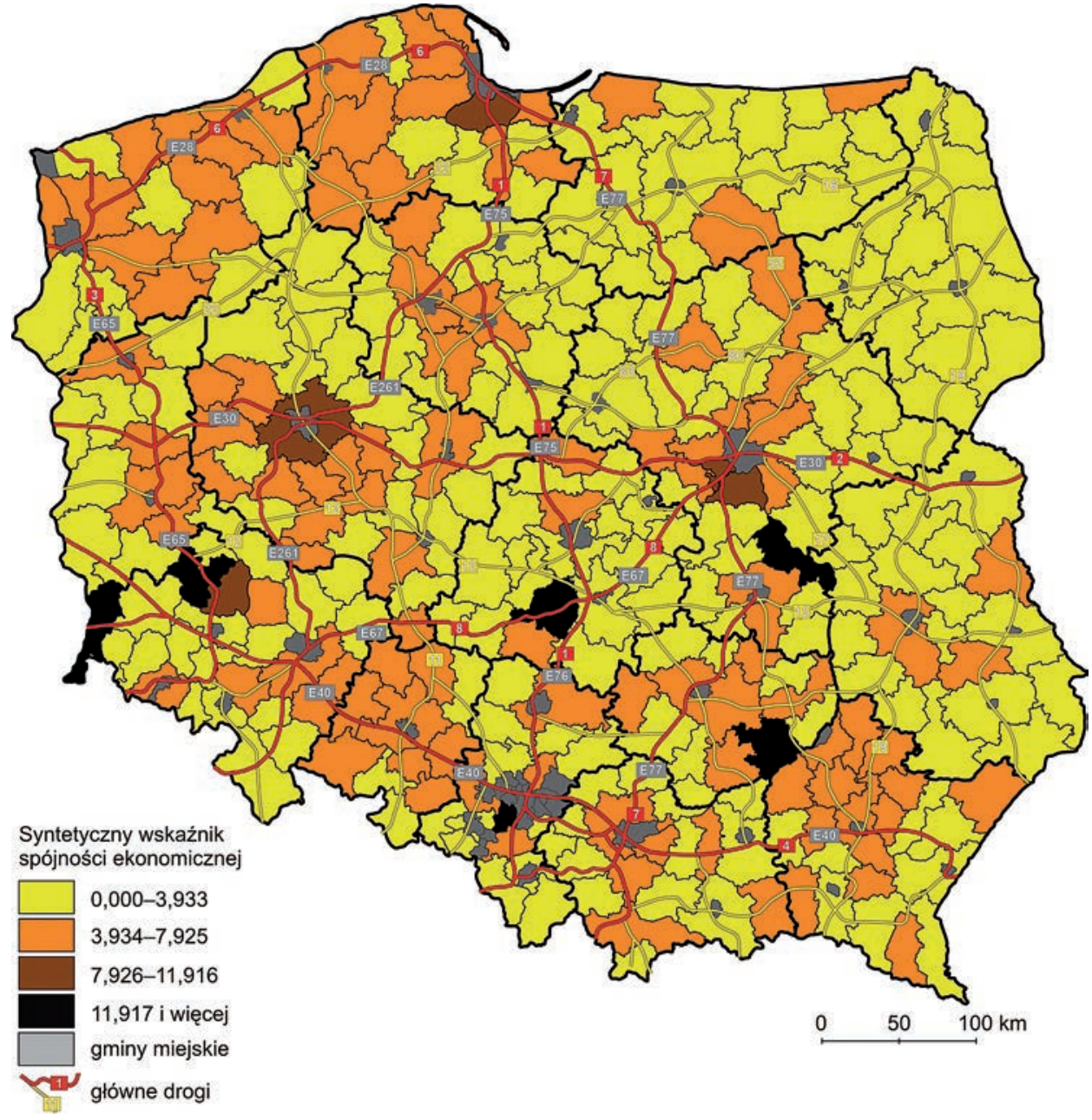

Ryc. 2. Przestrzenne zróżnicowanie syntetycznego wskaźnika spójności ekonomicznej na obszarach wiejskich w Polsce

Źródło: opracowanie własne.

3,455 i był wyższy prawie 2,5-krotnie aniżeli w klasie pierwszej i blisko o $50 \%$ niż w klasie drugiej. Natomiast wskaźnik spójności finansowej wyniósł 1,289 i również kształtował się powyżej analogicznego wskaźnika obliczonego dla klasy pierwszej i drugiej, ale przewaga ta nie była już tak spektakularna jak w przypadku infrastruktury i gospodarki.

Do ostatniej, czwartej grupy, zaliczono obszary o bardzo wysokiej spójności ekonomicznej (wskaźnik spójności 11,917 i więcej). W jej skład weszło 6 powiatów (kozienicki, staszowski, zgorzelecki, mikołowski, bełchatowski, polkowicki) skupiających łącznie około 1,5\% ludności wiejskiej kraju. Były to obszary o dobrze rozwiniętych funkcjach przemysłowych, w których funkcjonował przynajmniej 1 zakład o znaczeniu ponadregionalnym. W powiecie kozienickim była to 
elektrownia Kozienice w Świerżach Górnych, w powiecie staszowskim elektrownia Połaniec i Zakłady Chemiczne Siarki Siarkopol w Grzybowie i Osieku. Z kolei w powiecie zgorzeleckim ze względu na pokłady węgla brunatnego dominującą gałęzią gospodarki był przemysł wydobywczy i energetyczny. Podstawowe znaczenie miały kopalnia węgla brunatnego i elektrownia Turów. W obrębie powiatu mikołowskiego rozwinął się przemysł wydobywczy, energetyczny i hutniczy. Zlokalizowanych było tam 10 obszarów górniczych, w tym węgiel wydobywano w kopalniach: Bielszowice, Bolesław Śmiały, Budryk, Halemba. W Łaziskach Górnych funkcjonowała elektrownia.

Na terenie powiatu bełchatowskiego dominował przemysł wydobywczy, energetyczny, gumowy i produkcja materiałów budowlanych. Największe zakłady przemysłowe to: Kopalnia Węgla Brunatnego Bełchatów S.A., oraz elektrownia Bełchatów, która była liderem pod względem przychodów w powiecie i drugim pod względem wielkości pracodawcą. Znaczenie elektrowni dla powiatu wynikało z dużego bezpośredniego jej wpływu na lokalny i regionalny rynek pracy (zatrudnienie wynosiło ok. 4700 osób) oraz z faktu, że była dużym zleceniodawcą dla wielu firm w regionie (Strategia rozwoju... 2005).

Natomiast w powiecie polkowickim gospodarka powiatu związana była z przemysłem wydobywczym. KGHM Polska Miedź S.A. był jednym z największych na świecie producentów miedzi, soli i srebra. Na obszarze powiatu funkcjonowały także fabryki międzynarodowych koncernów, takich jak: Volkswagen, Royal Europa, Sitech.

\section{Zależność między kapitałem ludzkim a spójnością ekonomiczną obszarów wiejskich w Polsce}

Badania wykazały, że istnieje co najwyżej umiarkowana zależność statystyczna pomiędzy kapitałem ludzkim a spójnością ekonomiczną obszarów wiejskich. Współczynnik korelacji (liczony dla wszystkich powiatów) wyniósł 0,173, a współczynnik determinacji 0,030 (tab. 5, ryc. 3). Na bardzo niskim poziomie

Tabela 5. Współczynniki korelacji R i determinacji $\mathrm{R}^{2}$ między kapitałem ludzkim a wskaźnikiem spójności ekonomicznej

\begin{tabular}{|c|c|c|c|c|c|}
\hline & \multirow[b]{2}{*}{ Wyszczególnienie } & \multirow{2}{*}{$\begin{array}{c}\text { Syntetyczny } \\
\text { wskaźnik spójności } \\
\text { ekonomicznej }\end{array}$} & \multicolumn{3}{|c|}{ Wskaźnik spójności } \\
\hline & & & $\begin{array}{l}\text { finan- } \\
\text { sowej }\end{array}$ & $\begin{array}{l}\text { gospo- } \\
\text { darczej }\end{array}$ & $\begin{array}{l}\text { infrastruk- } \\
\text { turalnej }\end{array}$ \\
\hline \multirow{4}{*}{$\begin{array}{l}\text { Odsetek osób } \\
\text { z wykształ- } \\
\text { ceniem co } \\
\text { najmniej } \\
\text { średnim }\end{array}$} & R (dla całej zbiorowości) & 0,173 & 0,264 & 0,080 & 0,310 \\
\hline & $\mathrm{R}^{2}$ (dla całej zbiorowości) & 0,030 & 0,070 & 0,006 & 0,096 \\
\hline & $\begin{array}{l}\text { R (dla zbiorowości pomniejszo- } \\
\text { nej o jednostki o danych }>3 \sigma \text { ) }\end{array}$ & 0,404 & 0,293 & 0,215 & 0,327 \\
\hline & $\begin{array}{c}\mathrm{R}^{2} \text { (dla zbiorowości pomniejszo- } \\
\text { nej o jednostki o danych }>3 \sigma \text { ) }\end{array}$ & 0,163 & 0,085 & 0,046 & 0,106 \\
\hline
\end{tabular}

Źródło: Obliczenia własne. 


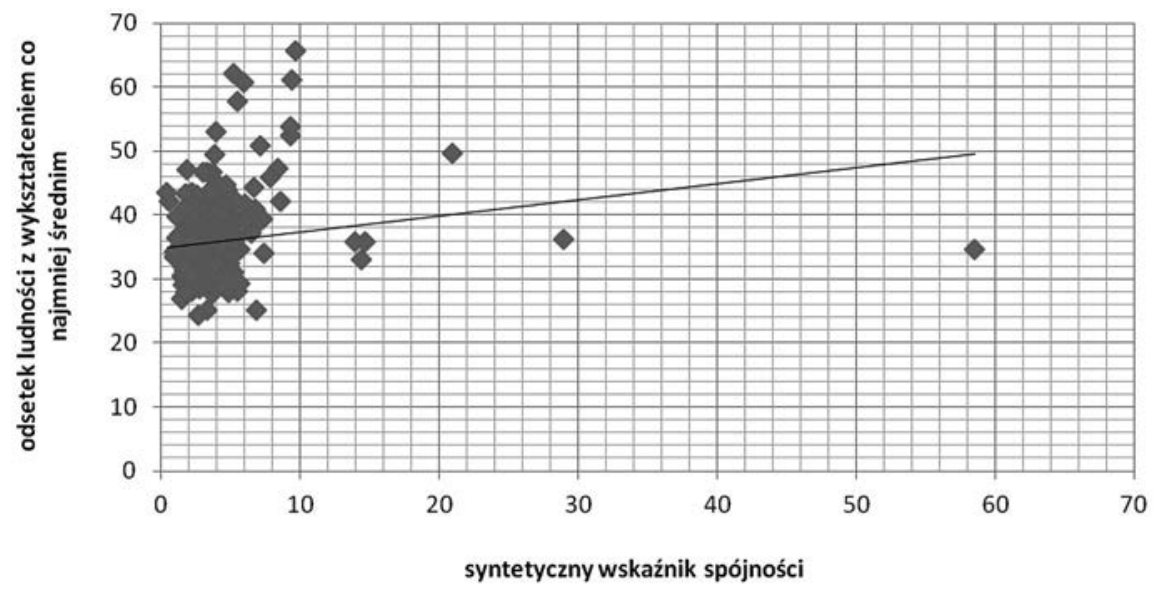

Ryc. 3. Zależność między odsetkiem osób z wykształceniem co najmniej średnim a syntetycznym wskaźnikiem spójności ekonomicznej

Źródło: opracowanie własne.

kształtowały się także obydwa współczynniki liczone pomiędzy poziomem wykształcenia a spójnością finansową, gospodarczą i infrastrukturalną obszarów wiejskich. Powyższe współczynniki poprawiają się w sytuacji, gdy liczono je z pominięciem powiatów znacznie odbiegających od istniejących tendencji (wskaźnik spójności $>3 \sigma$ ). Ale i wówczas współczynnik korelacji wynosi 0,404, co wskazuje na umiarkowaną zależność, a współczynnik determinacji 0,163. A zatem można stwierdzić, że to nie poziom formalnych kwalifikacji decydował w głównej mierze o sytuacji gospodarczej powiatów, ale inne czynniki stymulowały ich rozwój.

Tylko $\mathrm{w}$ około $17 \%$ jednostek przestrzennych ponadprzeciętnemu odsetkowi osób z wykształceniem co najmniej średnim odpowiadał ponadprzeciętny wskaźnik spójności ekonomicznej (tab. 6, ryc. 4). W tej grupie znalazły się powiaty:

1. Położone w strefie podmiejskiej dużych miast (np. poznański, krakowski, gdański, piaseczyński, pruszkowski, kielecki, częstochowski, toruński).

Tabela 6. Relacje między kapitałem ludzkim a poziomem spójności ekonomicznej

Wyszczególnienie

Ponadprzeciętny odsetek osób z wykształceniem co najmniej średnim/ ponadprzeciętny wskaźnik spójności ekonomicznej

Niższy od średniej odsetek osób z wykształceniem co najmniej średnim/ niższy od średniej wskaźnik spójności ekonomicznej

Ponadprzeciętny odsetek osób z wykształceniem co najmniej średnim/ niższy od średniej wskaźnik spójności ekonomicznej

Niższy od średniej odsetek osób z wykształceniem co najmniej średnim/ ponadprzeciętny wskaźnik spójności ekonomicznej

Razem

Źródło: opracowanie własne.

\section{Liczba Odsetek} powiatów powiatów

$52 \quad 16,6$

126

40,1

77

24,5

59

18,8

100,0


2. Z ugruntowaną pozycją dobrze rozwiniętego pozarolniczego rynku pracy opartego na bazie surowcowej i/lub lokalizacji przynajmniej jednego zakładu przemysłowego o znaczeniu ponadregionalnym (np. mikołowski, bełchatowski, lubiński, gliwicki, wielicki, policki).

3. Położone na obszarach atrakcyjnych turystycznie, „modnych” turystycznie, głównie nadmorskich i górskich (np. pucki, koszaliński, leski).

Relatywnie najwięcej powiatów z tej grupy zlokalizowanych było w województwie podkarpackim (prawie, co 3 jednostka przestrzenna) (tab. 7). W województwach podlaskim i warmińsko-mazurskim nie było ani jednego powiatu charakteryzującego się ponadprzeciętnymi wartościami obydwu zmiennych. Na uwagę zasługuje województwo wielkopolskie, na którego terenie tylko jeden powiat (poznański) spełniał przyjęte kryteria. Jak wykazują badania (Kacprzak 2010, Kamińska 2014a, b) w województwie tym (na obszarach wiejskich) wystąpiła zdecydowana nadreprezentacja osób z wykształceniem zasadniczym zawodowym w stosunku do potencjału demograficznego. Ludność wiejska przez cały okres centralnego sterowania bardziej preferowała zdobycie konkretnego zawodu aniżeli podnoszenie akademickich kwalifikacji. Stąd z jednej strony obszary te

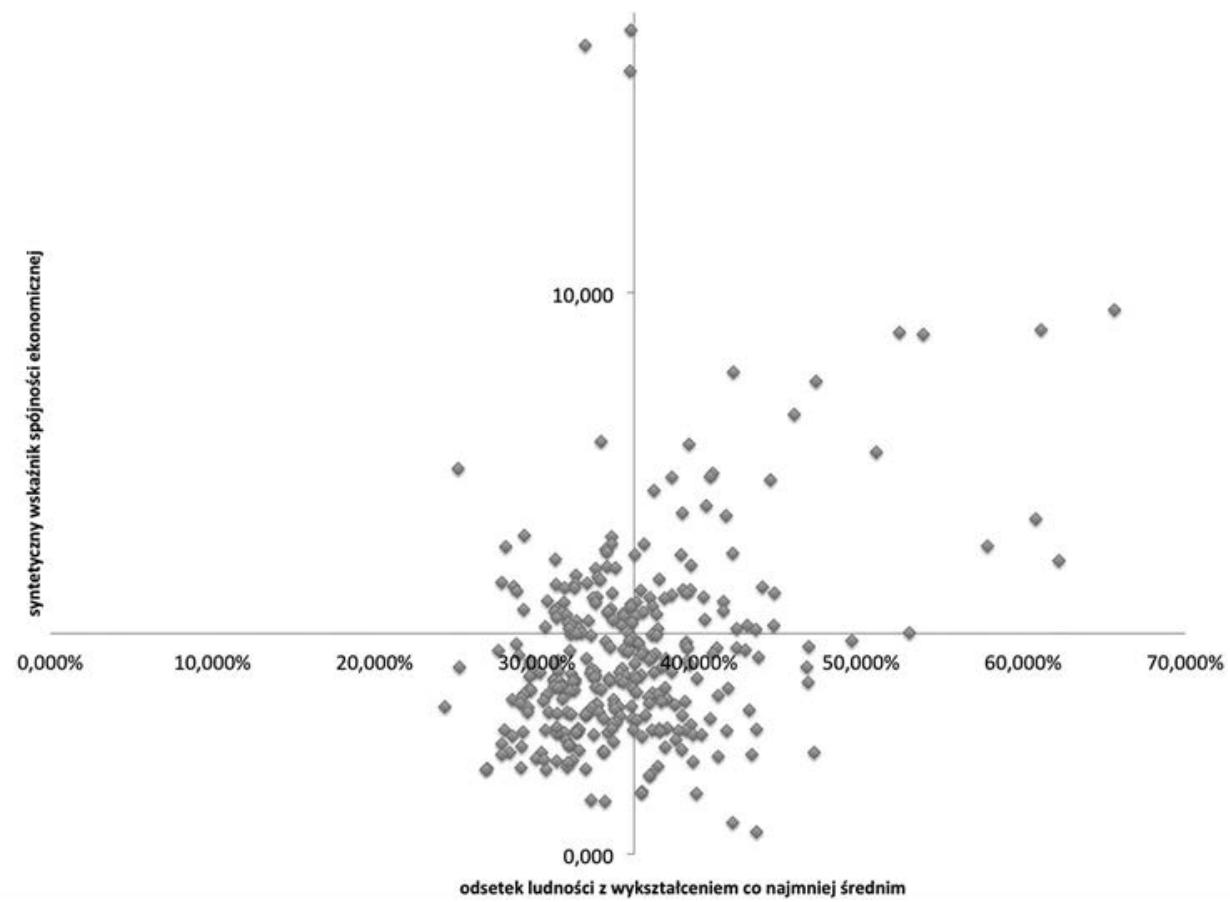

Ryc. 4. Zależność między kapitałem ludzkim a spójnością ekonomiczną obszarów wiejskich w Polsce

Osie przecinają się w punkcie o współrzędnych: 3,3 (OY) i 37\% (OX). Są to wartości średnie w zakresie badanych wskaźników dla obszarów wiejskich.

Źródło: opracowanie własne. 
Tabela 7. Liczba powiatów w poszczególnych grupach według województw

\begin{tabular}{llllll}
\hline \multirow{2}{*}{ Województwo } & \multicolumn{2}{c}{ Liczba powiatów (odsetek powiatów w stosunku do ich } & \\
\cline { 2 - 4 } & \multicolumn{2}{c}{ liczby w województwach) odznaczających się: } & razem \\
\cline { 2 - 4 } Łódzkie & $2(9,5)$ & $10(47,6)$ & $7(33,3)$ & $2(9,5)$ & 21 \\
Mazowieckie & $8(21,6)$ & $16(43,2)$ & $9(24,3)$ & $4(10,8)$ & 37 \\
Małopolskie & $4(21,1)$ & $6(31,6)$ & $7(26,8)$ & $2(10,5)$ & 19 \\
Śląskie & $5(29,4)$ & $1(5,9)$ & $11(64,7)$ & $0(0,0)$ & 17 \\
Lubelskie & $3(15,0)$ & $8(40,0)$ & $9(45,0)$ & $0(0,0)$ & 20 \\
Podkarpackie & $7(33,3)$ & $0(0,0)$ & $8(38,1)$ & $6(28,6)$ & 21 \\
Podlaskie & $0(0,0)$ & $11(78,6)$ & $3(21,4)$ & $0(0,0)$ & 14 \\
Świętokrzyskie & $2(15,4)$ & $3(23,1)$ & $4(30,8)$ & $4(30,8)$ & 13 \\
Lubuskie & $3(25,0)$ & $6(50,0)$ & $2(16,7)$ & $1(8,3)$ & 12 \\
Wielkopolskie & $1(3,2)$ & $15(48,4)$ & $1(3,2)$ & $14(45,2)$ & 31 \\
Zachodniopomorskie & $3(16,7)$ & $7(38,9)$ & $2(11,1)$ & $6(33,3)$ & 18 \\
Dolnośląskie & $7(26,9)$ & $7(26,9)$ & $10(38,5)$ & $2(7,7)$ & 26 \\
Opolskie & $3(27,3)$ & $2(18,2)$ & $1(9,1)$ & $5(45,5)$ & 11 \\
Kujawsko-pomorskie & $2(10,5)$ & $14(73,7)$ & $1(5,3)$ & $2(10,5)$ & 19 \\
Pomorskie & $2(12,5)$ & $5(31,3)$ & $1(6,3)$ & $8(50,0)$ & 16 \\
Warmińsko-mazurskie & $0(0,0)$ & $15(78,9)$ & $1(5,3)$ & $3(15,8)$ & 19 \\
\hline Razem & $52(16,6)$ & $126(40,1)$ & $77(24,5)$ & $59(18,8)$ & 314 \\
\hline & & & nwe $)$ & \\
\hline
\end{tabular}

Objaśnienia: ww/wse - ponadprzeciętny odsetek osób z wykształceniem co najmniej średnim/ponadprzeciętny wskaźnik spójności ekonomicznej; nw/nse niższy od średniej odsetek osób z wykształceniem co najmniej średnim/niższy od średniej wskaźnik spójności; ww/nse ponadprzeciętny odsetek osób z wykształceniem co najmniej średnim/niższy od średniej wskaźnik spójności ekonomicznej; nw/wse - niższy od średniej odsetek osób z wykształceniem co najmniej średnim/ ponadprzeciętny wskaźnik spójności ekonomicznej.

Źródło: opracowanie własne.

odznaczają się wysokim stopniem spójności, z drugiej zaś niskim odsetkiem osób z wykształceniem co najmniej średnim.

W 40\% powiatów niski (poniżej średniej dla obszarów wiejskich) odsetek osób z przyjętym poziomem edukacji korespondował z niskim wskaźnikiem spójności gospodarczej. Była to najliczniejsza grupa powiatów i obejmowała obszary rozciągające się niemalże równoleżnikowo: północne części województw wielkopolskiego i kujawsko-pomorskiego, północne i wschodnie rejony województwa mazowieckiego oraz prawie w całości województwa warmińsko-mazurskie i podlaskie.

Relatywnie najwięcej powiatów o niekorzystnym poziomie obydwu zmiennych znajdowało się w województwach: warmińsko-mazurskim (prawie 80\% ich ogólnej liczby), podlaskim (ok. 80\%), kujawsko-pomorskim (ok. 74\%) i lubuskim (50\%). A zatem ich rozmieszczenie nawiązywało do położenia obszarów, o znacznym udziale użytków rolnych gospodarstw uspołecznionych (por. 
Zgliński 2000). W województwie podkarpackim żaden z powiatów nie należał do tej grupy. Natomiast najmniej jednostek przestrzennych cechujących się niskim poziomem zarówno spójności ekonomicznej, jak i wykształcenia ludności było w woj. śląskim (ok. 6\%).

W co czwartym powiecie korzystnej strukturze wykształcenia (ponadprzeciętny odsetek osób z wykształceniem co najmniej średnim) odpowiadał niski poziom spójności ekonomicznej.

Skoncentrowane one były głównie na południu kraju oraz między Łodzią a Warszawą.

W tej grupie znalazły się powiaty:

1. O dobrze rozwiniętych funkcjach przemysłowych - na tych terenach pozarolnicze zatrudnienie wymagało podwyższenia kwalifikacji ludności (np. bieruńsko-lędziński, olkuski, łódzki wschodni, bialski, myszkowski, pabianicki, wałbrzyski, oświęcimski, chrzanowski, skarżyski). Wymienione jednostki przestrzenne w okresie centralnego sterowania wchodziły w skład największych okręgów przemysłowych i już w 2002 r. odznaczały się ponadprzeciętnym udziałem ludności z wykształceniem średnim i wyższym w ogólnej liczbie ludności dorosłej (por. Kamińska 2014a, b).

2. Położone w sąsiedztwie dużych i średnich miast - dostępność do szkół średnich i wyższych ułatwiała podnoszenie formalnych kwalifikacji (np.: przemyski, nowosądecki, grójecki, wodzisławski).

3. Na terenie których funkcjonowały szkoły wyższe (najczęściej powstałe po 1990 r. państwowe wyższe szkoły zawodowe) (np. jarosławski, sanocki, zamojski, krośnieński).

4. Położone na terenach górskich - gdzie rozwój infrastruktury, ze względu na ukształtowanie powierzchni lub/i duże rozproszenie sieci osadniczej, był opóźniony w stosunku do innych regionów kraju (żywiecki, cieszyński, bocheński, legnicki, dzierżoniowski, kłodzki, makowski, sanocki, bieszczadzki). Relatywnie najwięcej takich jednostek znajdowało się w województwach: śląskim, dolnośląskim i podkarpackim, a najmniej w wielkopolskim, kujawsko-pomorskim, pomorskim, opolskim i warmińsko-mazurskim.

W prawie co 5 powiecie pomimo niekorzystnej struktury wykształcenia ludności odnotowano wysoki wskaźnik spójności ekonomicznej. W układzie przestrzennym zidentyfikowano 3 ich skupiska: na Pomorzu, w Wielkopolsce oraz na granicy województw podkarpackiego i świętokrzyskiego. Północno-zachodnie obszary (tzw. ziemie odzyskane po II wojnie światowej), jak już wspomniano, zawsze były lepiej wyposażone w infrastrukturę techniczną aniżeli inne regiony Polski (Węcławowicz i in. 2006). Dodatkowo położenie nadmorskie, a w przypadku województwa zachodniopomorskiego i przygraniczne stanowiło czynnik rozwoju zarówno drobnej przedsiębiorczości, jak i lokalizacji kapitału zagranicznego. Te uwarunkowania wpłynęły na ponadprzeciętne kształtowanie się mierników opisujących wszystkie 3 aspekty syntetycznego wskaźnika spójności ekonomicznej. W przypadku województwa wielkopolskiego sytuacja jest nieco odmienna. Wysoka spójność ekonomiczna ma swoje uwarunkowania historyczne i współczesne. Przynależność do zaboru pruskiego i wynikająca z tego kultura przedsiębiorczości 
oraz dobry stan zainwestowania $\mathrm{w}$ infrastrukturę techniczną, położenie przy zachodniej granicy (dobre połączenia komunikacyjne), napływ kapitału zagranicznego, wysokie wskaźniki przedsiębiorczości uplasowały obszary wiejskie Wielkopolski wśród liderów pod względem spójności ekonomicznej. Z drugiej strony pragmatyka ludności wiejskiej powodowała wybieranie takiej ścieżki edukacji, która zapewniała konkretny zawód, a więc często zasadniczych szkół zawodowych. Odbijało się to na niższym (od przeciętnego dla obszarów wiejskich) odsetku osób $z$ wykształceniem co najmniej średnim. Z kolei położenie obszarów $z$ analizowanej grupy na Podkarpaciu nawiązywało do Centralnego Okręgu Przemysłowego, co z jednej strony miało związek z ponadprzeciętnym wskaźnikiem spójności, a z drugiej były to rejony odpływu ludności zwykle młodej i dobrze wyedukowanej (Baran, Kopacz-Wyrwał 2014), co ukształtowało niekorzystną strukturę ludności według wykształcenia.

Należy podkreślić, że $\mathrm{w}$ tej grupie znaleźli się także liderzy, czyli powiaty, w których zanotowano najwyższe wskaźniki spójności (powyżej 11,917): polkowicki, zgorzelecki, staszowski, kozienicki. Dominująca funkcja przemysłowa wpłynęła na spójność ekonomiczną, ale rozwijające się na tym terenie gałęzie przemysłu (wydobywczy, hutniczy, energetyczny) nie były wrażliwe na wysoko wykształconą kadrę, co miało wpływ na strukturę ludności według wykształcenia.

\section{Wnioski}

Przeprowadzona analiza pozwala stwierdzić, że istnieje co najwyżej umiarkowana statystyczna zależność między poziomem kapitału ludzkiego mierzonym odsetkiem ludności z wykształceniem co najmniej średnim a poziomem spójności ekonomicznej obszarów wiejskich. Współczynnik korelacji liczony dla całej zbiorowości jednostek przestrzennych wyniósł 0,173 , a determinacji 0,03. Oznacza to, że zmienność (wariancja) spójności ekonomicznej tylko w 3\% była wyjaśniana zmiennością kapitału ludzkiego, w 97\% innymi czynnikami. Bardzo niskie współczynniki korelacji i determinacji stwierdzono też między kapitałem ludzkim a wskaźnikami spójności infrastrukturalnej, finansowej oraz gospodarczej. Badania przeprowadzone wśród zbiorowości powiatów pomniejszonej o jednostki drastycznie odbiegające od zauważonych tendencji (dane $>3 \sigma$ ) wskazują na wzrost współczynnika korelacji do 0,404, a współczynnika determinacji do 0,163, co oznacza, że zmienność spójności ekonomicznej tylko w $16 \%$ była wyjaśniana zmiennością kapitału ludzkiego, a w 84\% innymi czynnikami.

Ponadprzeciętne wartości obydwu zmiennych zanotowano niemalże wyłącznie na obszarach o wysokiej rencie położenia - w sąsiedztwie miast wojewódzkich (z wyjątkiem Białegostoku i Olsztyna). Powiązania funkcjonalne dużych ośrodków z ich wiejskim zapleczem dawały gwarancję dobrego rozwoju gospodarczego, infrastrukturalnego i finansowego obszarów wiejskich. Oczywiście nie wszystkie powiaty sąsiadujące $z$ aglomeracjami osiągnęły jednakowo spektakularny sukces. Do grupy liderów zaliczały się te, które były najlepiej skomunikowane z miastami. Można postawić tezę, że dobra dostępność komunikacyjna nie była czynnikiem 
„wypychającym” ludność (w tym najlepiej wykształcona), a wręcz przeciwnie była faktorem "przyciągającym” imigrantów. Powiaty o ponadprzeciętnych wartościach syntetycznego miernika spójności i korzystnej strukturze wykształcenia mieszkańców zwykle położone były w pierwszym pierścieniu okalającym największe miasta kraju. Były to obszary o dobrze rozwiniętych funkcjach pozarolniczych (Bański, Stola 2002), wysokich wskaźnikach przedsiębiorczości (Kamińska 2006), ponadprzeciętnym poziomie rozwoju infrastruktury technicznej (Węcławowicz $i$ in. 2006), dodatnim saldzie migracji (Rosner 2010) oraz wysokim odsetku osób o najwyższych kwalifikacjach (Kamińska 2014a). Wszystkie te cechy sprzyjają zarówno spójności ekonomicznej, jak i akumulacji kapitału ludzkiego. Trudno jednak stwierdzić, która z nich była pierwotna, a która wtórna. Oddziaływały one synergicznie na poszczególne powiaty sprzyjając osiąganiu sukcesów gospodarczych.

Niekorzystną sytuację pod względem badanych cech zaobserwowano głównie na obszarach Polski północnej i wschodniej (podlaskie, warmińsko-mazurskie, północna część kujawsko-pomorskiego i wielkopolskiego). Były to tereny typowo rolnicze, słabo zaludnione, odznaczające się odpływem migracyjnym. Wymienione cechy nie sprzyjają ani spójności ekonomicznej, ani korzystnej strukturze według wykształcenia.

Z kolei niską spójność i ponadprzeciętny odsetek osób wysoko wykształconych odnotowano głównie na obszarach Polski południowej. Taka sytuacja była wypadkową dwóch czynników. Po pierwsze wysoki stopień uprzemysłowienia, gęsta sieć miast umożliwiały podnoszenie kwalifikacji mieszkańców. Po drugie ukształtowanie powierzchni nie sprzyjało szybkiemu rozwojowi infrastruktury technicznej (por. Makieła 1998). Dodatkowo duży odsetek obszarów chronionych ograniczał rozwój przedsiębiorczości na niektórych terenach.

Natomiast niekorzystne wykształcenie ludności i wysoka spójność ekonomiczna charakteryzuje obszary, których rozwój związany był z bazą surowcową głównie z przemysłem wydobywczym (węgiel kamienny, brunatny, miedź, siarka) oraz energetyką i hutnictwem. Wpływ tego typu zakładów na lokalny i regionalny rynek pracy oraz na budżety samorządów lokalnych był na tyle duży, że klasyfikowały się one w czołówce najbogatszych jednostek przestrzennych w kraju. Jak dotąd nie miało to jeszcze odzwierciedlenia w wykształceniu ludności.

Jak wynika $z$ powyższych badań, na obecnym poziomie rozwoju i w konkretnych warunkach przyrodniczych, społecznych, gospodarczych i kulturowych polskich obszarów wiejskich poziom wykształcenia jest nisko (lub umiarkowanie - w przypadku usunięcia „danych odstających”) skorelowany z ich spójnością ekonomiczną. Z całą pewnością wyniki zależą od przyjętych cech. Można się, na przykład, spierać, czy dla obszarów wiejskich lepszym miernikiem kapitału ludzkiego nie byłby udział osób z wykształceniem zasadniczym zawodowym. Ale i w takim przypadku współczynniki korelacji i determinacji były na niskim poziomie $(0,192$ i 0,04$)$.

Powyższe uwagi skłaniają do refleksji, że obszary wiejskie położone atrakcyjnie będą nadal rozwijać się szybciej od innych. Nawet takie, na których infrastruktura nie nadąża za innymi aspektami rozwoju społeczno-gospodarczego. Przy odpowiednim poziomie kapitału ludzkiego wykorzystają one inne szanse 
wypływające z procesów globalizacji i integracji (np. rozwój turystyki). Obszary, na których gospodarka oparta jest na ciężkim, szkodliwym dla środowiska naturalnego przemyśle, powinny dziś zainwestować zgromadzone pieniądze $\mathrm{w}$ przemysły wysokiej techniki i w kapitał ludzki. Tereny peryferyjne zaś nie poradzą sobie same. Nawet prowadzona od 2004 r. polityka spójności nie wpłynęła w znaczącym stopniu na zmniejszanie się różnic wewnątrz- i międzyregionalnych.

\section{Literatura}

Bański J., Stola W. 2002. Przemiany struktury przestrzennej i funkcjonalnej obszarów wiejskich. Studia Obszarów Wiejskich, 3.

Baran E., Kopacz-Wyrwał I. 2014. Poziom życia a procesy depopulacji na obszarach wiejskich południowo-wschodniej Polski. [W:] W. Kamińska, K. Heffner (red.), Polityka spójności UE a rozwój obszarów wiejskich: stare problemy i nowe wyzwania. Studia KPZK PAN, CLIV:125-147.

Baran E., Grzebyk B. 2011. Zrównoważony rozwój obszarów wiejskich Podkarpacia. Stan i perspektywy. Prace Naukowe Wydziału Ekonomii Uniwersytetu Rzeszowskiego, seria: Monografie i Opracowania, 13.

Brol R. 1996. Procesy urbanizacji wsi polskiej. Monografie i Opracowania. Wyd. AE, Wrocław.

Celińska-Janowicz D., Kozak M., Miszczuk A., Płoszaj A., Smętkowski M., Tucholska A., Wojnar K. 2010. Ocena wpływu polityki spójności na rozwój miast polskich (w ramach ewaluacji ex post NPR 2004-2006). EUROREG i Ministerstwo Rozwoju Regionalnego, Warszawa.

Chojnicki Z., Czyż T. 2003. Polska na ścieżce rozwoju gospodarki opartej na wiedzy. Podejście regionalne. Przegląd Geograficzny, 71,1: 23-39.

Churski P. (red.) 2009. Spójność i konkurencyjność regionu wielkopolskiego. Raport końcowy z realizacji zadania publicznego o charakterze naukowo-badawczym $\mathrm{w}$ postaci badania naukowego, $\mathrm{w}$ zakresie wdrażania funduszy strukturalnych na poziomie Narodowej Strategii Spójności (Program Operacyjny Pomoc Techniczna, Umowa z Ministerstwem Rozwoju Regionalnego DKS/DEF-VIII/POPT/04/275 /09.). Publikacja elektroniczna. Poznań.

Ciok S., Rabczyk A. 2006. An Evolution of the Implementation of Polish-German Cross-border Cooperation within INTERREG IIIA. Conference Paper presented at Towards Sustainable Border Region - Analysis, Strategies and Approaches for Transboundary Spatial Development.

Czapiński J. 2008. Kapitał ludzki i kapitał społeczny a dobrobyt: polski paradoks. Zarządzanie Publiczne, UE, Kraków, 4: 5-28

Dyba W.M., Stryjakiewicz T. 2012. Zróżnicowanie poziomu rozwoju społeczno-gospodarczego gmin województwa wielkopolskiego w świetle realizacji polityki intraregionalnej. Biuletyn Instytutu Geografii Społeczno-Ekonomicznej i Gospodarki Przestrzennej UAM, seria: Rozwój Regionalny i Polityka Regionalna, 19.

Gałczyńska B. 1998. Zróżnicowanie przestrzenne poziomu wykształcenia ludności rolniczej w Polsce. [W:] Gospodarka przestrzenna obszarów wiejskich Polski. XV Ogólnopolskie Seminarium Geograficzno-Rolnicze, Białystok-Torun.

Gałczyńska B., Kulikowski R. 1986. Poziom wykształcenia zatrudnionych w rolnictwie a efekty produkcyjne. Przegląd Geograficzny, 58: 783-794.

Gąska J., Kozłowski W., Koloch G., Lis M., Regulski A., Skrok Ł. 2009. Spójność wewnętrzna a konkurencyjność regionu tódzkiego. Diagnoza strategiczna. Raport z badań. Instytut Badań Strukturalnych, Warszawa.

Gołębiewska B., Klepacki B. 2004. Wykształcenie rolników jako forma różnicująca sytuację gospodarstw rolniczych. [W:] M.G. Woźniak (red.), Kapitał ludzki i intelektualny jako czynnik wzrostu gospodarczego i ograniczania nierówności społecznych. Wyd. Mittel, Rzeszów, s. 457-465.

Gorzelak G. 2007. Strategiczne kierunki rozwoju Polski Wschodniej, Ekspertyza przygotowana na potrzeby „Strategii rozwoju społeczno-gospodarczego Polski Wschodniej do roku 2020”. MRR, Warszawa. 
Hryniewicz J.T. 2000. Endo- i egzogenne czynniki rozwoju gospodarczego gmin i regionów. Studia Regionalne i Lokalne, 2(2): 53-77.

Jabłoński Ł. 2005. Kapitał ludzki a tempo wzrostu polskiej gospodarki, [W:] Nierówności społeczne a wzrost gospodarczy: kapitał ludzki i intelektualny. 1. 6. Wyd. URz., Rzeszów.

Janc K. 2009. Zróżnicowanie kapitału ludzkiego i społecznego w Polsce. Rozprawy Naukowe Instytutu Geografii i Rozwoju Regionalnego UWr, 8. Wrocław.

Janc K., Czapiewski K.Ł. 2005. Wykształcenie czynnikiem wspierającym rozwój gospodarczy obszarów wiejskich. [W:] B. Głębocki, U. Kaczmarek (red.), Obszary sukcesu na polskiej wsi. Studia Obszarów Wiejskich, 8: 69-84.

Kacprzak E. 2010. Przestrzenne zróżnicowanie kapitału ludzkiego i społecznego na obszarach wiejskich woj. wielkopolskiego. [W:] W. Kamińska, K. Heffner (red.), Kapitał ludzki i społeczny w procesie rozwoju obszarów wiejskich. Studia KPZK PAN, CXXVI: 161-180.

Kamińska W. 1999. Rozwój działalności gospodarczej sektora prywatnego na obszarze wschodniego pogranicza w Polsce w latach 1988-1997. [W:] R. Horodeński, M. Rościszewski (red.), Wschodnia Strefa Działalności Gospodarczej. Wydawnictwo WSE, Białystok, s. 205-227.

Kamińska W. 2006. Pozarolnicza indywidualna działalność gospodarcza w Polsce w latach 1988-2003. Prace Geograficzne 203, IGiPZ PAN, Warszawa.

Kamińska W. 2010a. Przestrzenne zróżnicowanie kapitału ludzkiego i społecznego na obszarach wiejskich województwa świętokrzyskiego. [W:] W. Kamińska, K. Heffner (red.), Kapitał ludzki i społeczny w procesie rozwoju obszarów wiejskich. Studia KPZK PAN, Warszawa, CXXVI: 120-143.

Kamińska W. 2010b. Urbanizacja obszarów wiejskich województwa świętokrzyskiego. IG UJK, Kielce.

Kamińska W. 2011. Kapitał ludzki i społeczny na obszarach wiejskich w Polsce. Przykład województwa świętokrzyskiego. IG UJK, Kielce.

Kamińska W. 2013. Rural areas in Poland: Educational attainment vs. level of economic development. Quaestiones Geographicae, 32(4): 63-79.

Kamińska W. 2014a. Przemiany struktury i poziomu wykształcenia ludności wiejskiej w Polsce w latach 2002-2011. [W:] W. Kamińska, K. Heffner (red.), Polityka spójności UE a rozwój obszarów wiejskich: stare problemy i nowe wyzwania. Studia KPZK PAN, CLIV: 93-123.

Kamińska W. 2014b. Structural Transformation of Education Level in Rural Poland - A Spatial Approach. [W:] W. Kamińska, K. Heffner (red.), Rural Development and EU Cohesion Policy. Studia Regionalia KPZK PAN, 39: 95-115.

Kamińska W., Mularczyk M. 2014. Assessment of the Economic Cohesion of Rural Areas in Poland. A Dynamic and Spatial Approach. [W:] W. Kamińska, K. Heffner (red.), Rural Development and EU Cohesion Policy, Studia Regionalia KPZK PAN, 39: 41-67.

Klimczak K. 2002. Inwestycje w kapitał ludzki i społeczny a wzrost gospodarczy Polski. Sytuacja gospodarcza Polski. SKNNE Ekspert, Łódź.

Kołodziejczyk D. 2014. Territorial perspective on the economic and social cohesion of gminas in Poland. [W:] Kamińska W., Heffner K. (red.), Rural Development and EU Cohesion Policy, Studia Regionalia KPZK PAN, 39.

Komornicki T., Śleszyński P., Siłka P. 2012. Charakterystyka systemu osadniczego województwa podkarpackiego z identyfikacją biegunów wzrostu oraz wyróżnieniem obszarów funkcjonalnych na poziomie regionalnym i lokalnym. Ekspertyza wykonana w ramach prac nad aktualizacją i uzupełnieniem Strategii Rozwoju Województwa Podkarpackiego 2007-2020. IGiPZ PAN, Warszawa.

Kulikowski R. 2001. Problemy społeczne wsi i rolnictwa w Polsce, [W:] J. Bański, E. Rydz (red.), Społeczne problemy wsi. Studia Obszarów Wiejskich, 2: 9-17.

Kulikowski R. 2013. Produkcja i towarowość rolnictwa w Polsce. Przemiany i zróżnicowanie przestrzenne po II wojnie światowej. IGiPZ PAN, Warszawa.

Lopez-Bazo E., Moreno R. 2008. Does human capital stimulate investment in physical capital? Evidence from a coast system framework. Economic Modeling, 25: 1295-1305.

López-Rodriguez J., Faiña J.A., Lopez-Rodriguez J. 2007. Human capital accumulation and geography: empirical evidence from the European Union. Regional Studies, 41(2): 217-234.

Makieła Z. 1998. Infrastruktura techniczna w strukturze regionalnej Polski południowo-wschodniej. Wyższa Szkoła Pedagogiczna im. Komisji Edukacji Narodowej w Krakowie, Kraków.

Roszkowska S. 2006. Kapitał ludzki a wzrost gospodarczy w Polsce w ujęciu regionalnym. [W:] E. Okoń-Horodyńska, K. Piech (red.), Unia Europejska w kontekście Strategii Lizbońskiej oraz gospodarki i społeczeństwa wiedzy w Polsce. Instytut Wiedzy i Innowacji, Warszawa. 
Rosner A. 2010. Przestrzenne zróżnicowanie kapitału ludzkiego na obszarach wiejskich w Polsce. [W:] W. Kamińska, K. Heffner (red.), Kapitał ludzki i społeczny w procesie rozwoju obszarów wiejskich. Studia KPZK PAN, CXXVI: 49-65.

Rudnicki R. 2010. Zróżnicowanie przestrzenne wykorzystania funduszy Unii Europejskiej przez gospodarstwa rolne w Polsce w latach 2004-2006. Studia i Prace z Geografii i Geologii, 17. Bogucki Wydawnictwo Naukowe, Poznań.

Sobala-Gwosdz A. 2003. Zróżnicowanie poziomu rozwoju gmin przygranicznych województwa podkarpackiego. [W:] J. Runge (red.), Granice, obszary przygraniczne, euroregiony. UŚ, Katowice, s. $249-262$.

Stawicka E., Wołoszyn J. 2007. Wiedza rolników jako determinanta w rozwoju gospodarstw rolnych. [W:] K. Piech, E. Skrzypek (red.), Wiedza w gospodarce, społeczeństwie, przedsiębiorstwach: pomiary, charakterystyka, zarządzanie. Instytut Wiedzy i Innowacji, Warszawa, s. 260-273.

Strategia rozwoju powiatu bełchatowskiego na lata 2005-2015, 2005. Poznań

Swianiewicz P. 2007. Strategiczna analiza stanu spójności ekonomicznej i społecznej przeprowadzona na poziomie obszarów Nuts 4 i Nuts 5 . Ekspertyza przygotowana na potrzeby aktualizacji „Strategii rozwoju społeczno-gospodarczego Polski Wschodniej do roku 2020". MRR, Warszawa.

Swianiewicz P., Herbst J., Lackowska M., Mielczarek A. 2008. Szafarze darów europejskich. Kapitał społeczny a realizacja polityki regionalnej w polskich województwach. Wyd. Nauk. Scholar, Warszawa.

Ślusarz G. 2005. Studium społeczno-ekonomicznych uwarunkowań rozwoju obszarów wiejskich w świetle zagrożenia marginalizacją na przykładzie województwa podkarpackiego. Prace Naukowe Wydziału Ekonomii URz, Monografie i Opracowania, 1. Wyd. URz, Rzeszów.

The Well-being of nations. The role of human and social capital. 2001. Centre for Educational Research and Innovation. OECD, Paris.

Wawrzyniak B.M. 2001. Luka edukacyjna barierą procesu integracji polskiej wsi i rolnictwa Unii Europejskiej. Wieś i Rolnictwo, 3(112): 142-159.

Węcławowicz G., Bański J., Degórski M., Komornicki T., Korcelli P., Śleszyński P. 2006. Przestrzenne zagospodarowanie Polski na początku XXI wieku. Monografie, 6. IGiPZ PAN, Warszawa.

Wpływ wspólnej polityki rolnej i polityki spójności na rozwój obszarów wiejskich. Raport końcowy. 2011. Fundeco Inicjatywa Dobrych Praktyk, Warszawa.

Zaleski J., Kudełko J., Mogiła Z., Tomaszewski P., Zembaty M. 2010, Efekty realizacji Polityki Spójności Unii Europejskiej w województwie dolnośląskim, ze szczególnym uwzględnieniem wpływu Regionalnego Programu Operacyjnego Województwa Dolnośląskiego na lata 2007-2013 przy użyciu modelu regionalnego HERMIN. Wrocławska Agencja Rozwoju Regionalnego S.A., Wrocław.

Zgliński W. 2000. Szanse rozwoju wielofunkcyjnego na obszarach postpegeerowskich. [W:] A. Stasiak (red.), Możliwości wielofunkcyjnego rozwoju wsi polskiej w kontekście integracji z Unią Europejską. Studia KPZK PAN, CX: 181-204.

Zioło Z. 2010, Rola zasobów intelektualnych, kapitału ludzkiego i społecznego w procesach rozwoju obszarów wiejskich. [W:] W. Kamińska, K. Heffner (red.), Kapitał ludzki i społeczny w procesie rozwoju obszarów wiejskich. Studia KPZK PAN, CXXVI: 9-20.

\title{
Human capital vs. economic cohesion of rural areas in Poland
}

\begin{abstract}
The aim of this study was to determine the relationship between human capital understood as the knowledge of society and the degree of economic cohesion of rural areas in Poland. Synthetic index based on the 9 measures showing the financial, economic and infrastructure situations in rural areas was constructed to examine the economic cohesion. As a measure of human capital, a proportion of the population with at least secondary education was adopted. The analysis was performed at the level of counties. The study showed that there is a weak or moderate relationship between the studied traits. The coefficient correlation calculated for all counties was only 0.173 , and the coefficient of determination was 0.03 . In contrast, the correlation coefficient calculated for the number of spatial units reduced by the districts drastically differ from the observed trend was 0.404 , and the coefficient of determination was 0.163 . This means that the level of economic coherence determine other factors.
\end{abstract}

Key words: economic cohesion, education, rural areas 